\title{
Parkia pendula lectin as histochemistry marker for meningothelial tumour
}

\author{
E.I.C. Beltrão, ${ }^{1}$ P.L. Medeiros, ${ }^{2}$ O.G. Rodrigues, ${ }^{3,4}$ J. Figueredo-Silva, ${ }^{1,5}$ M.M. Valença, ${ }^{6}$ \\ L.C.B.B. Coelho, ${ }^{7}$ L.B. Carvalho Jr${ }^{7}$ \\ ${ }^{1}$ Laboratório de Imunopatologia Keizo Asami - LIKA; ${ }^{2}$ Departamento de Histologia e Embriologia - UFPE, \\ ${ }^{3}$ Departamento de Antibióticos - UFPE; ${ }^{4}$ Departamento de Medicina Veterinária - UFPB; ${ }^{5}$ Departamento \\ de Patologia - UFPE; ${ }^{6}$ Departamento de Neurologia e Neuropsiquiatria - UFPE; ' Departamento de \\ Bioquímica - UFPE; Recife, Pernambuco, Brasil
}

\section{(C2003, European Journal of Histochemistry}

Lectins have been intensively used in histochemical techniques for cell surface characterization. These proteins are involved in several biological processes and their use as histochemical markers have been evaluated since they can indicate differences in cell surfaces. Parkia pendula lectin (PpeL) was evaluated as histochemical marker for meningothelial meningioma biopsies. Tissue slices were incubated with PpeL conjugated to horseradish peroxidase (PpeL-HRP) and Concanavalin A-HRP (ConA-HPR) and the binding visualized with diaminobenzidine and hydrogen peroxide. The lectin-tissue binding was inhibited with D-glucose. PpeL showed to be a useful tool for the characterization of meningothelial tumour and clinico-pathological diagnosis.

Correspondence: L.B. Carvalho Júnior, Laboratório de Imunopatologia Keizo Asami, Universidade Federal de Pernambuco, Cidade Universitária, Recife, 50670-420, Pernambuco, Brazil. Phone: international +55.81 .32718486 . Fax: international +55.81.32718484. E-mail: Ibcj@hotlink.com.br

Key words: meningioma; lectin histochemistry; Parkia pendula.

Paper accepted on October 10, 2002.

European Journal of Histochemistry 2003; vol. 47 issue 2 [Apr-Jun]:139-142
$\mathrm{M}$ eningiomas belong to a group of predominantly benign tumours of adults. They develop from the meningothelial cells of the arachnoid, although they are most intimately associated with the dura. This type of brain tumour accounts for the most frequent primary intracranial neoplasms in adults. In 1993, no less than 14 variants of this meningothelial tumour were included in the revised edition of the World Health Organization (WHO) histological classification of central nervous system tumours and characterized meningiomas with an increased propensity to recur (WHO, 2000).

Plant lectins, especially those purified from seeds, have found a great number of applications in medicine and biological processes such as infection, cell differentiation and metastasis (Goldstein et al., 1980; Barondes, 1988; Sharon and Lis, 1990, 1993). As histochemical marker, lectins have been used to characterize mammary (Beltrão et al., 1998), uterine (Remani et al., 1994) and cerebral neoplasic tumours (Schumacher et al., 1995; Marafioti et al., 1994; Salmon et al., 1996, Wiley and Kline, 2000; Nishimura et al., 2000).

Lectin histochemistry has been used as an extra marker besides the traditional immunohistochemistry to characterize normal and transformed tissues. Human meningiomas were studied with lectins such as Peanut agglutinin (PNA), Canavalia ensiformis (Con A), Ulex europaeus 1 (UEA-1), Dolichos biflorus (DBA) and Triticum vulgaris (WGA) (Marafioti et al., 1994). Histiocytic and xanthoma cells were detected differentially to vascular elements within meningiomas using lectin histochemistry (Kleinert and Radner, 1987; Herling et al., 2000).

The cytochemical binding intensity of some lectins is of value in distinguishing between different me- 
ningioma subgroups. Fibroblastic meningioma cells are more strongly recognized by WGA and UEA-1 than the meningothelial subtype (Salmon et al., 1996).

Parkia pendula lectin (PpeL) is extracted from the seeds of a native tree from Atlantic Forest of the State of Pernambuco, Northeast Brazil. The tree belongs to the family Fabaceae and sub-family Mimosoideae. PpeL recognizes glucose and mannose and belongs to the same family of Concanavalin A (Con A), purified from Canavalia ensiformis seeds and the Isoform 1 of Cratylia mollis (Cra Iso 1) lectin, a seed lectin purified from a native forage legume from the Semiarid Region of the State of Pernambuco (Correia and Coelho, 1995).

The high incidence of meningothelial tumours diagnosed in the Neurology Sector of the Clinic Hospital at the Federal University of the State of Pernambuco (UFPE) raised the interest to investigate this brain pathology using lectin histochemistry.

In this work Parkia pendula lectin is evaluated as histochemical tool to help the clinico-pathological evaluation of meningiomas.

\section{Materials and Methods Lectins}

PpeL was purified from seeds of Parkia pendula tree at the Laboratory of Glycoprotein at the Department of Biochemistry - UFPE. PpeL was labeled with horseradish peroxidase (HRP) as described by Avrameas et al. (1976). Concanavalin A-HRP (Con A-HRP) was purchased from Sigma Company. Lectin binding inhibition assays were accomplished using D-glucose from Sigma Company.

\section{Meningioma specimens}

Five formalin-fixed and paraffin-embeded meningioma biopsies were obtained from the Neurology Sector of the Clinic Hospital at the Federal University of Pernambuco - UFPE. Patient ages varied between 40 and 50-year-old at the time of surgery.

\section{Staining procedure}

Four-micrometer paraffin sections were cut and microscope slides were prepared. Sections were deparaffinized in xylene and hydrated through graded alcohol (100-70\%). Tissue slices were treated with a $0.1 \%(\mathrm{w} / \mathrm{v})$ trypsin solution at $35^{\circ} \mathrm{C}$, for $2 \mathrm{~min}$, followed by $0.3 \%(\mathrm{v} / \mathrm{v})$ methanol-hydrogen peroxide for $30 \mathrm{~min}$ at room temperature and then incubated with PpeL-HPR $(75 \mu \mathrm{g} / \mathrm{mL})$ and Con A-HPR $(60 \mu \mathrm{g} / \mathrm{mL})$ overnight. All solutions were prepared in $10 \mathrm{mM}$ phosphate buffer, containing $0.15 \mathrm{M} \mathrm{NaCl}$ (PBS), pH 7.2. After each step, the slices were immersed in PBS for two 5-min washes. Peroxidase was visualized using diaminobenzidine (DAB) solution containing hydrogen peroxide for 5-8 min. Sections were counterstained with haematoxylin. Lectin binding was evaluated on an Olympus $\mathrm{BH}-2$ light microscope. Assays for lectin binding inhibition were accomplished incubating each lectin solution with $\mathrm{D}$-glucose $(0.02$ to $0.5 \mathrm{M}$ ) for 15 min prior to its incubation with the tissue. Following steps were as described previously for the binding protocol.

\section{Results and Discussion}

Lectins bind to carbohydrates of cell surfaces in oligosaccharides or glycoconjugates (Goldstein et al., 1980; Barondes, 1988; Sharon and Lis, 1990, 1993; Kennedy et al., 1995).

Qualitative and quantitative changes in the glycosylated components of cell surface could be significant in the development and progression of pathologic processes, including neoplasic ones (Karuna et al., 1992; Brooks, 1995; Astoul et al., 2000; Nishimura et al., 2000). Beltrão et al. (1998) evaluated normal and transformed mammary tissues with Cra Iso 1 and Con A. Their results support the use of lectins as histochemical tool for tissue differentiation/characterization since the more malignant the more intense lecting staining was observed.

In the five specimens studied the staining of meningioma cells with PpeL $(75 \mu \mathrm{g} / \mathrm{mL})$ characterized the syncytial cell aspect in the tissue (Figure 1 ) and the outline endothelial blood vessels. Con A, used as a pattern of glucose/mannose binding lectin presented a similar staining. The PpeL and Con A binding were completely abolished with D-glucose at the concentration of $300 \mathrm{mM}$ (Figure 2).

PpeL showed similar results to those observed using lectin histochemistry for human meningiomas (Marafioti et al., 1994; Salmon et al., 1996; Wiley and Kline, 2000; Nishimura et al., 2000).

Lectin binding pattern diversity allows different histological sub-types of meningioma to be distinguished although the biological significance of 

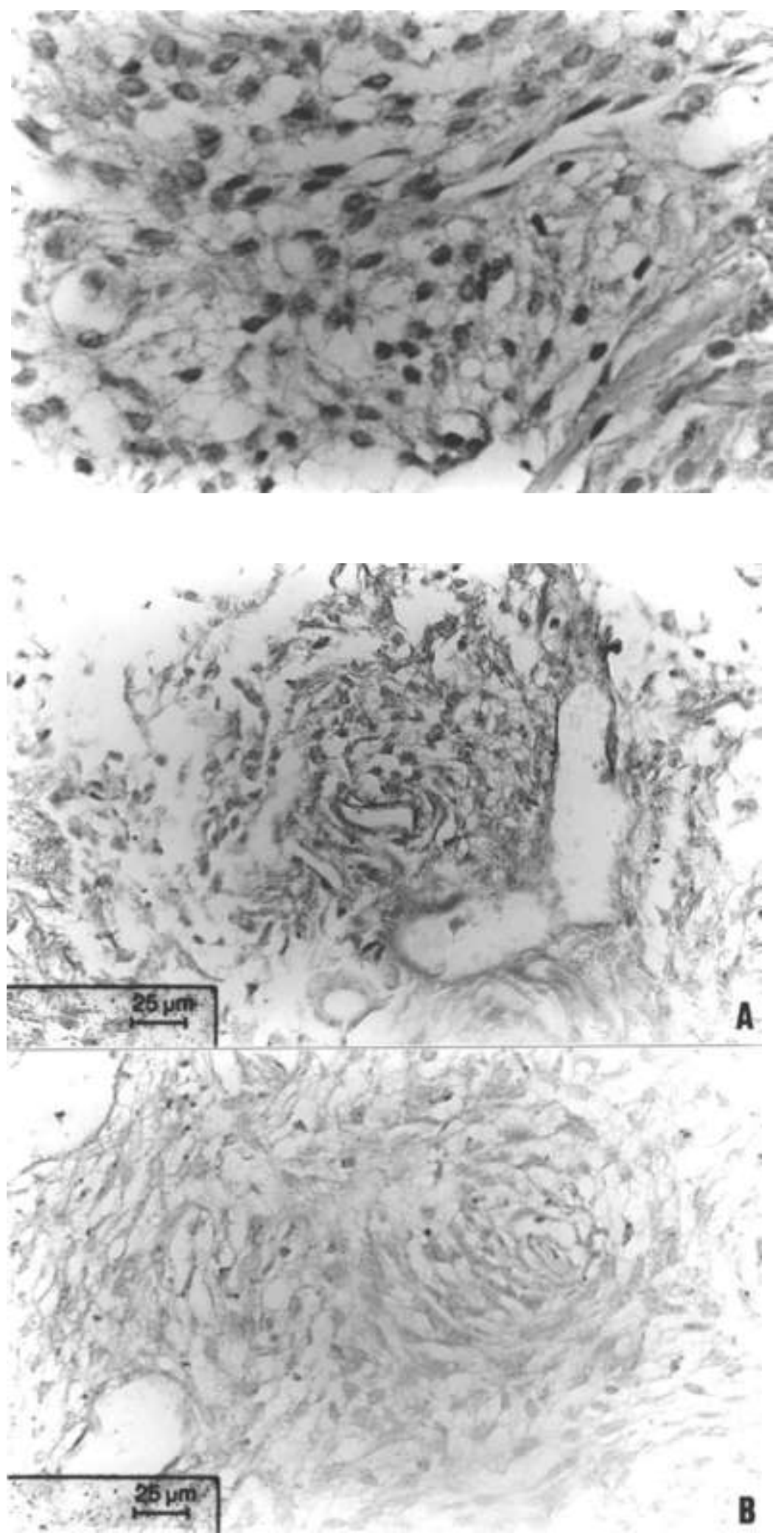

Figure 1. Meningothelial tumour stained with PpeL-HRP. Syncytial aspect of meninge cells is characterized by the lectin staining. binding patterns is unclear (Kleiner and Radner, 1987). Our findings show that PpeL presented reactivity patterns and expressed strong cytoplasmatic staining in a number of cells, which allowed the characterization of meningothelial sub-type.

The bulk of evidence obtained from previous researches indicates that monosaccharide composition and biochemical metabolism in brain cells 
change with age and dedifferentiation thus lectins may be also useful as histochemical markers for investigating senile changes in the brain (Kiatipattanasakul et al., 1998; Yoshihara et al, 1999) and moreover, morphologic aspects of tumours (Jeong et al., 1996, Probst-Cousin et al., 1997).

In the current study, the benign cases of meningiomas used were followed for less than one year. Reasons for a relative lack of longer follow up periods in this population are unknown. However, this may be related to a better post-treatment prognosis than for the fact that malignant meningiomas are so hard to be diagnosed. The survival rate in patients with either condition is increased in those who have undergone surgical treatment.

Our results demonstrate that $\mathrm{PpeL}$ is a promising histochemistry marker to distinguish differentiation in meningioma tumours the meningothelial variant and to show details of cytoplasm, morphologic cell features and endothelial arrangement of blood vessels in the tumour studied. It also allowed characterization of meningothelial form indicating a relevant clinico-pathological differentiation.

\section{Acknowledgments}

This work was supported by the National Council for Technological and Scientific Development (CNPq - CTPETRO $n^{\circ}$ 463655/001) and the Foundation for Science Assistance Support of the State of Pernambuco (FACEPE). We thank Carmelita de Lima Bezerra Cavalcanti and Paulina Maria Santos de Albuquerque for their technical assistance.

\section{References}

Astoul $\mathrm{CH}$, Peumans WJ, Van Damme EJ. Accessibility of the highmannose glycans of glycoprotein gp120 from human immunodeficiency virus type 1 probed by in vitro interaction with mannose-binding lectins. Biochem Biophys Res Commun 2000;274:455-60.

Avrameas S, Karsenti E, Bornes M. Peroxidase - Concanavalina A Method: Application in Light and Electron Microscopy. In: Bittiger $\mathrm{H}$, Schnebli HP, Eds. Concanavalin A as a Tool. London: John Wiley and Sons; 1976. p. 85-93.

Barondes SH. Bifunctional properties of lectins: lectins redefined: Trends Biochem Sci 1988;13:480-2.

Beesley JE. In: Immunocytochemistry. A Practical Approach. Oxford University Press: Oxford; 1993.

Beltrão EIC, Correia MTS, Figueredo-Silva J, Coelho LCBB. Binding evaluation of isoform 1 from Cratylia mollis lectin to human mammary tissues. Appl Biochem Biotech 1998;74:125-34.
Brooks S, Leathem AJC. Expression of $\alpha$-GalNAc glycoproteins by breast cancers. Br J Cancer 1995;71:1033-8.

Correia MTS, Coelho LCBB. Purification of a glucose/mannose specific lectin, Isoform 1, from seeds of Cratylia mollis Mart. (Camaratu bean). Appl Biochem Biotech 1995;55:261-73.

Cushing $H$, Eisenhardt L. In: The meningiomas. vol.3. Thomas CC, Ed. Springfield; 1938.

Goldstein IJ, Hughes RC, Monsigny M, Osawa T, Sharon N. What should be called a lectin? Nature 1980;285:66.

Herling M, Knolle J, Bahn H, Gabius HJ, Richter KK, Rath FW, et al. Glycohistochemical monitoring of chemically induced sarcomas at different stages of tumorigenesis. In Vivo 2000;14:499-506.

Jeong HS, Lee GK. Secretory meningioma - a case report with histopathological, immunohistochemical and structural analysis. J Korean Med Sci 1996;11:369-72.

Karuna $V$, Shanti $P$, Madhavan M. Lectin binding patterns in benign and malignant lesions of the breast. Indian $\mathrm{J}$ Pathol Microbiol 1992;35:289-97.

Kennedy JF, Paiva PMG, Correia MTS, Cavalcanti MSM, Coelho LCBB. Lectins, versatile protein of recognition: a review. Carbohydr Polym 1995;24:219-30.

Kepes JJ. Presidential addressing: the histopathology of meningiomas. A reflection of origins and expected behavior? J Neuropathol Exp Neurol 1986;45:95.

Kiatipattanasakul W, Nakayama H, Nakamura S, Doi K. Histochemistry in the aged dog brain. Acta Neuropathol 1998;95:261-8.

Kleinert $\mathrm{R}$, Radner $\mathrm{H}$. Lectin binding in meningiomas. Neuropathol Appl Neurobiol 1987;4:263-72.

Marafioti T, Barresi G, Batolo D. Lectin histochemistry of human meningiomas. Histol Histopathol 1994;3:535-40.

Niedermayer I, Kolles H, Henn W, Zang KD, Studel WI, Feiden W. Meningioma. Classification and grading. Pathologie 1997;5:353-8.

Nishimura A, Sawada S, Ushiyama I, Yamamoto Y, Nakagawa T, Tanegashima A, et al. Lectin-histochemical detection of degenerative glycoconjugate deposits in human brain. Forensic Sci Int 2000; 113:265-9.

Probst-Cousin S, Villagran-Lillo R, Lahl R, Bergmann M, Schmid KW, Gullotta F. Secretory meningioma: clinical, histologic and immunohistochemical findings in 31 cases. Cancer 1997;79:2003-15.

Remani P, Pillai KR, Haseenabeevi VM, Ankathil R, Bhattathiri M, Nair MK, et al. Lectin cytochemistry in the exfoliative citology of uterine cervix. Neoplasma 1994;41:39-42.

Salmon I, Camby I, Remmelinck M, Rombaut K, Pasteels JL, Kiss R, et al. Lectin histochemistry, ploidy level and proliferation indices in meningioma subtypes Neuropathol Appl Neurobiol 1996;22:68-76.

Schumacher U, Adam E, Brooks SA, Leathem AJ. Lectin binding properties of human breast cancer cell lines and human milk with particular reference to Helix pomatia agglutinin. J Histochem Cytochem 1995;43:275-81.

Sharon N, Lis H. Legume lectins. A large family of homologous proteins. FASEB J 1990;4:3198-208.

Sharon N, Lis H. Carbohydrates in cell recognition. Sci Am 1993; 268:82-9.

Wiley RG, Kline IV. Neuronal lesioning with axonally transported toxins. J Neurosci Methods 2000;103:73-82.

WHO Classification of Tumours. Pathology and genetics of tumours of the nervous system. Kleihues P, Cavenee WK, Eds. IARC Press: Lyon; France. 2000.

Yoshihara $Y$, Mizuno $T$, Nakahira $M$, Kawasaki $M$, Watanabe $Y$, Kagamiyama $\mathrm{H}$, et al. A genetic approach to visualization of multisynaptic neural pathways using plant lectin transgene. Neuron 1999;1:33-41. 